\section{Poetics and Interaction in 21st Century Finland}

Helsinki Poetics Conference,

22 August 2007.

Considerable attention has been paid to the complexity of contemporary poetry in Finland. ${ }^{1}$ One could even say that there is a poetry boom going on in Finland. The media (television, internet and press) is suddenly interested in poetry, a fact highlighted by recent conferences and several poetry recitals that have been organised. The Poetics Conference is a part of Helsinki Festival's Poetry Moon, which is a prominent series of poetry events. The same is true of Poetry Week organised in Turku in November.

The third annual Helsinki Poetics Conference $^{2}$ presented views on poetics from the perspective of scholars and particularly contemporary Nordic poets (mostly Finnish). The title of the conference, "The Ir/responsibility of Poetry" (Runouden vastuu/ttomuus) was an invitation to ethical considerations. Several interesting and topical issues were raised in each of the addresses. Thematically they all seemed to share the idea of poetics as interaction, which is essential to ethics.

The event was opened by poet and translator Leevi Lehto, who is known for his experimentalism in poem generator poetry. ${ }^{3}$ Search-engine poetry is a symptom of a conception of poetry that is (optimistically) democratic in its interactionality: the poem takes after its reader, albeit in the confines of a certain menu. Lehto's address manifested the idea of poetics as a multitude of poetries instead of doctrines or formulae.

In the morning's first address Danish poet and journalist, Martin Glaz Serup, presented his version of the independent nature of poetry. Serup emphasised, that belief in an artistic truth is of major importance to a poet. A poem's voice, style, personality and imagery are the emblems of this artistic truth. Serup then relativised his idea of truthfulness: poetry's means eventually aim at reaching the other, the reader or the listener (and perhaps even the otherness in the author him/herself). ${ }^{4}$

The situationality of interpretation was exemplified by Serup's use of the late Finnish writer Pentti Saarikoski's lyrical prose citation (at the end of the novel Aika Prahassa from the 1960s) of the stone inside the bread. It is possible to interpret the metaphor as a political comment, but in addition - as mentioned by audience members - the framework of interpretation can also be the Bible or the cornerstone of Finnish culture, the Kalevala.

The framework of interpretation has to do with interaction, which can be included in the concept of poetics. According to Tuula Hökkä $(2001,8)$, we arrive at the domain of poetics when we discuss how an enjoyable work of art is made and when we ponder on literary creation, its conditions and effects. Thus, the recipient of a work of art (such as a collection of poetry), or, one who enjoys it, also shares 
in poetics. In addition, such an interactional relationship between poems and their recipients is always conditional. Interaction takes place in a confined situation. In other words, the context of interpretation as temporal, local, situational and communal is evident.

\section{The Contexts of Interaction}

Poet and scholar Pauliina Haasjoki questioned in her address whether poets are responsible for the effect of their poems on the reader. Ultimately her answer to the question seemed to be no, they are not. A poem can, in a sense, cause violence, or violate the reader if the dominant context of interpretation is amiable to violence or if the societal-cultural circumstance supports that kind of behaviour. Interpretations thus have their interactional consequences, and here the reader has a responsibility for the choices $s /$ he makes. There is always more than one interpretation, but their interconnections are worth consideration. As Haasjoki emphasised, a poem always contains contradiction and inscrutability, and hence specifying a direct effect and meaning is impossible.

Haasjoki, who has published three collections of poetry, has also recently published an essay on poetics from the perspective of reading and writing (2007). 5 Similarly, poet Panu Tuomi's collection of essays attests to the interactional conception of poetics (2006). ${ }^{6}$ In his address, Tuomi was on a similar track as Haasjoki. Responsibility and freedom are inextricably linked, as they should be, stated Tuomi, the author of six collections of poetry. He does not believe in a direct causal relation either. It then follows according to Tuomi that language is poetry's area of responsibility, and it is this responsibility for language that generates the communality of poetry and the reader's creative role. Poetry is then material and concrete interaction between texts and readers.

The ethical can broadly be understood as dialogism, as the orientation of a text towards an audience (see e.g., Pearce 2004, 20). This refers to interaction between different factors, which in turn means that the question of ethics in poetics covers poems, readers, authors, situations and time alike. At the moment, Finnish contemporary poetry aims at a more concrete and active approach to people than before. Concrete conditions -like cultural and financial atmosphere - also have their active part in creating, reading and hearing poetry.

In an impressive and indirect manner, that is to say in a manner specific to poetry, Panu Tuomi spoke about being interested in "futile issues like poetry". This can be regarded as a remark that is itself responsible: futility can be counteractive to a social order which uses the rapid accumulation of wealth and continuous increase in consumption as markers of success. For Tuomi, a poetics of form is one of poetry's crucial means. Such means for him are euphony (melody and sound), i.e., the expansion of meaning by virtue 
of the materiality of language, and also references to numerology and the Middle Ages.

\section{Turning toward and away from}

The afternoon's shorter addresses served to both expand and support the views presented in the morning. Poetics scholar Karoliina Lummaa questioned whether poetry is responsible to nature or for it. Responsibility is often connected to communication and humanity, but what about the nonhuman, nature and animals? A poem should, for its part, according to Lummaa, take responsibility for nature. We ought to formulate sites for nature in language. Precisely the language of poetry would enable the non-objectification of nature, the delineation of its diversity, the re-creation of the subject-object relation and a humble awareness of the fact that a human perspective cannot know, understand or perceive everything, as Lummaa stated. A reader is a part of this process that could be seen as actual ethics, when the aforementioned critical aspects become activated by a way of reading. In this way, the "futility" of poetry can show its true critical force, that is to say its usefulness in a global frame, too. The afternoon's second commentator, poet Kimmo Kallio stated that poetry should above all be responsible for its own renewal. As an example, Kallio used Pekka Tarkka's way of reading Paavo Haavikko, which was paradoxical as Haavikko is not so "new" anymore, since he debuted in the beginning of the 1950s.
Recently-debuted poet Miia Toivio's comment from the audience pointed out that "newness" was, above all, the intrinsic value of the Modernist era (in Finnish poetry it occurred in the 50s), and it can easily become a categorical and exclusive imperative. Another comment from the audience, this time from an anthropological perspective, emphasised that even a ritualistic symbol is different in each given time and situation. "The New" is thus a contextual conception.

Poetry scholar Katja Seutu's address suggested that a scholar of poetry, too, is responsible for forming poetics. What poets look for in poems, and why, is an important, but often neglected question according to her. Poetry has its relations to everyday life and the poetically political - that is, ethical questions - but this has not received enough attention. In particular, Seutu has found herself faced with fundamental questions when it comes to the role poem. What does it mean to take a role? What is the relationship to real life, when the poem's speaker is a historical person? In Seutu's opinion, there is a shortage of tools for this kind of examination as well as a lack of discussion between scholars.

Finding answers to Seutu's questions would enable us to see the interactionality of poetics at large, in its sense of turning toward and away from. This is also how we approach the very core of poetics, questions of what poetry means. The question is also of the unresolved and complex relationship between poetry 
and reality, which has to be renegotiated continuously with regard to each work of poetry, each poet's oeuvre, and each era.

One of the final commentators in the afternoon, blogger Esa Mäkijärvi provoked the audience with his ambiguous statements. According to him, lyrical poetry ought to be brought to the new millennium with a bang, with poet Risto Ahti's debut novel from forty years ago in the lead! Multiartist Räsänen-Rogers presented a text that emphasised, among other things, the importance of a woman's identity. A more fictional tone served to highlight the significant difference in texts: a factual text is received and interpreted differently than its fictional sister. Translator and Classicist Sampo Vesterinen's stream-of-consciousness culminated in guilt: many issues have been distorted, and we the people are responsible.

To end the day, Jukka Mallinen, PEN activist and critic, cited views by contemporary poets in St. Petersburg, according to whom it is still necessary to resist everything poetical, that is to say automatisation. Such responsible resistance can cut into structures and work as a critical counterforce (and as a way of perhaps repairing some misinterpretations).

\section{Toward an Ethical Study of Poetry}

Poetics could be defined according to the conference speakers as a simultaneous, multi-dimensional movement. Thus, it means an interactive process that demands several active subjects that are poets, poems, readers, critics and scho- lars, and the world. The most often heard plea, argument or wish in the conference had to do with the importance of interaction and participation: a poem does not exist separately from the world. On the contrary, a poem's very contact zone could be empowering and truly ethical. It is interesting to note, that the significance of rhythm was brought up by many, implicitly or explicitly.

This trend can also be seen in contemporary Finnish poetry. In terms of scholarship, rhythm has been in the periphery, but it could serve to highlight the many affective effects of poetry. Previously, rhythm has been characterised as poetry's impressive, enchanting and magical force, and it is often in a deliciously ambivalent way connected to femininity or poetry written by women. Rhythm is somehow connected to the material side of language, and yet it is, too, somehow hard to define by strict conceptions.

The study of poetry, as a part of poetics in the way it was defined above, does not have to be prescriptive, but rather something founded on the idea of interaction. A work of poetry under analysis is thus not just the "object", but rather an active part of the research process which affects what is being studied and how. In addition, a group or a community involved in formulating poetics needs to be accounted for as an influential frame (Bal 2000, 481-485). Diversity and plurality enable the previously inconceivable interpretation to be written and articulated orally in an ethical sense. That is why 
poetry readings are popular, because neither poetry nor its study is about reading silently, but about commonality and sharing, which does not mean homogeneity but differences, too.

\section{Siru Kainulainen}

\section{Translated with Elina Valovirta}

\section{Notes}

${ }^{1}$ See, e.g., Helsingin Sanomat 19 March 2006; 6 May 2007; 8 September 2007.

${ }^{2}$ The conference was organised by the poetry society Nihil Interit, the journals Tuli\&Savu, niin \& näin and Nuori Voima, the Departments of Finnish Literature and Comparative Literature at the University of Helsinki, Finnish Literary Research Society, Tutkijaliitto ('Scholars' Alliance') and the Scandinavian portal of The Electronic Poetry Center. The last in English at [http://www. leevilehto.net/epc/index.html].

${ }^{3}$ See web site in English at [http://www. leevilehto.net] (19 October 2007).

${ }^{4}$ Serup's poetry has been translated into Finnish in the anthology Tämä ei ole fiktiota. 18 pohjoismaista nykyrunoilijaa (Teos 2007). 5 The other essayists featured in the volume are contemporary Finnish poets Jarkko Tontti, Johanna Venho, Tapani Kinnunen, Joni Pyysalo, Timo Hännikäinen and Janne Nummela.

${ }^{6}$ The series Runoilija pubuu ('The Poet Speaks') has also published essays by Mirkka Rekola (2007). In addition, for example Helena Sinervo (2006) has pondered the poetics of her poetry. Rekola and Sinervo's poems - along with other contemporary Finnish poets - are available in English at [http://www.electricverses.net] (19 October 2007).

\section{Bibliography}

BAL, Mieke 2000: Poetics, Today. Poetics Today 21:3. Available at [http://muse.jhu.edu/journals/poetics_ today/toc/poet21.3.html] (28 September 2007).

HAASJOKI, PAULIINA 2007: Miten ihmeellisyyttä kuunnellaan ja miten se kehystetään. Poetiikkaa - seitsemän esseetä runouskäsityksistä. Edited by Ville Hytönen and Ville-Juhani Sutinen. Turku: Savukeidas. нӧкKÄ, TUULA 200I: Runouskäsitykset liikkeessä. Romanttinen Moderni. Kirjoituksia runouskäsityksistä. Edited by Tuula Hökkä. Helsinki: SKS.

PEARCE, LYNNE 2004: The Rhetorics of $\mathrm{Fe}$ minism. Readings in Contemporary Cultural Theory and the Popular Press. London and New York: Routledge.

REKOLA, MIRKKA 2007: Esittävästä todellisuudesta. Esseitä. Tampere: Sanasato.

SINERVO, HELENA 2006: Kuvan ja sanan kynnyksellä. Sukupolveni runous. Parnasso 4/2006.

TUOMI, PANU 2006: Poeettinen korrektius. Esseitä ja muita kirjoituksia. Tampere: Sanasato. 